derm larvæ were observed. The character of the samples remained the same during the first part of August, but in addition some Rhizosolenia spp. (?) were observed. On August 16 a very unusual phenomenon was observed when taking the water sample. The sea was found to be a distinct chocolate-brown colour and very turbid. A sample was taken in a glass jar and the colour was seen to be due to vast numbers of a small greenish-brown organism just sufficiently large to be distinguished by the naked eye. Examination in the laboratory later on showed it to be a flagellated organism, which I was unable to identify. The plankton sample consisted almost entirely of masses of this organism. I do not know how far the coloration extended, but it was observed from aircraft for at least 70 miles along the coast. 'The phenomenon persisted for days, and when the next weekly sample was taken there were still masses of the organism in the plankton sample. During the first part of September Coscinodiscus sp. and Choetoceros spp. composed the bulk of the catch, and later on Noctiluca sp. (probably N. scintillans) predominated.

An examination of the data obtained from the samples appears to indicate that there is an influx of cold ocean water along the sea-board of the Colony during the months of July, August and September. This may be due to an upwelling of deep ocean water on to the continental shelf, or to cold ocean water from the South Atlantic Ocean finding its way into the current which flows for the greater part of the year from west to east along the sea-board of the Colony. It is probably not without significance that this influx of cold water, slightly more soline and richer in phosphate, coincides roughly with the main fishing season along the greater part of the coast of the Colony, when two species of Sardinella- $S$. aurita and $S$. cameronensis-are caught in large quantities.

It is hoped to continue and extend this work in the near future.

\section{THE PUBLIC SCHOOLS OF BRITAIN}

\section{By the Rev. CANON SPENCER LEESON Headmaster, Winchester College}

$\mathrm{T}$ HE public schools question has been somewhat in abeyance in recent months. Among the reasons for this is that the larger share of public attention in this province has been given to the Education Act, and the numerous administrative measures that are required to bring it into effective operation; and also that up to now the negotiations between the Ministry, on one hand, and the associations of governing bodies for boys' schools and girls' schools, the headmasters and headmistresses on the other, have been confined to scheme $A$ of the Fleming Report, that is, the recommendations applying to what will be known in the future as direct-grant grammar schools. These negotiations are pretty well completed, and the revised regulations for directgrant grammar schools have now been published. Discussions on scheme $B$, that is, those recommendations that affect mainly the independent boarding schools and day schools, are just beginning; and we may therefore expect a revival of public interest in the future of those schools.

The Fleming Committee is to be warmly congratu- lated on producing a unanimous report on so difficult and controversial a question; and its whole discussion of the matter and its recommendations are clearly based on a wide and deep knowledge of conditions prevailing in the schools, and the concrete problems that have to be solved. Various proposals were put before them for the future regulation of the public schools. One extreme view was that they should be abolished altogether, their endowments taken over and their buildings dedicated to other educational purposes, hostels, residential courses in adult education and so forth. It is not likely that this view will be supported in any responsible quarter. Another suggestion was that the schools should be kept in operation, but should be handed over to the State to be run as part of the State educational service, boys and girls being allocated to them by public authority, and the schools being brought under full public control. The third proposal is that put forward by the Fleming Committee, namely, that the schools should remain independent, although open to inspection by the Ministry of Education and accepting to membership of their governing bodies public representatives up to not more than one third of the total number; and that they should reserve each year 25 per cent of their admissions for boys and girls who have previously been educated at primary schools, the expense, as calculated on a fee to be agreed upon for each school between the schools and the Ministry, to be met from public funds in so far as the parents themselves are unable to pay the full cost. It is around these recommendations that, no doubt, the coming negotiations will centre; and we may hope that in a few months some measure of agree. ment will be reached. It is made clear in the report that the co-operation of the schools is to be voluntary from their side and that no compulsion should be applied to them.

I submit that in the settlement of this great national question we should endeavour to free ourselves from political preconceptions and prejudice on both sides. History shows that politics is no friend to education, and that where political considerations and especially party considerations are allowed to come in from either end, the work of the schools suffers. I suggest that we should put all this on one side and base ourselves on two propositions. The first is contained in section 76 of the Education Act, 1944 : ... "In the exercise and performance of all powers and duties conferred and imposed on them by this Act, the Minister and Local Education Authorities shall have regard to the general principle that, so far as is compatible with the provision of efficient instruction and training and the avoidance of unreasonable public expense, pupils are to be educated in accordance with the wishes of their parents". The second proposition is contained in the first recommendation on p. 100 of the Fleming Report ... "that opportunities of education in the schools included in our terms of reference (i.e., roughly speaking, the public schools), and in any such other schools as may be approved for the purpose by the Ministry of Education, be made available to boys and girls capable of profiting thereby, irrespective of the income of their parents". No considerations other than these have really any bearing on the matter. If it is argued that ex-primary pupils should be taken into the schools at public expense in order to preserve the latter from extinction, that argument has no validity; if the schools cannot stand on their own feet, they had much better disappear. On the 
other side, if it is argued that this infiltration, as it is called, of boys of one class into schools up to now reserved for boys of other classes, will have the effect of de-classing them, as it were, and detaching them from their former political and social allegiance, that also has no validity. Both are good examples of the wrong kind of approach. The only sensible and natural approach is surely this : Are there any parents who want their children to have boarding school education ? If so, is it fair or right that they should be debarred from obtaining that education for their children because they cannot afford to pay the fees? Clearly the answer to this second question must be : No. If the public schools have worked out an educational method and standard that parents believe to be valuable, ought access to those schools to be confined, as it is now, to exceptionally clever boys who win scholarships, and boys whose parents can afford to pay high fees ? Clearly, again, the answer must be: No. How, then, can we put matters right ? I suggest by the adoption of a doublepronged policy; first that the State should provide boarding schools of its own, and power to do this is conferred upon the State by the Act; and secondly, that the existing boarding schools should take post side-by-side with these schools that soon, we hope, will be created, making their contribution under proper conditions, but preserving their independence. This policy will give rein to the incontestable right of parents to decide within reasonable limits how their children shall be educated; and it will at the same time enable the public schools to make their offer without forfeiting their independence.

It may be asserted, in reply: Why should the schools be allowed to retain their independence? On that the schools are unanimous and emphatic. It is not in the public interest that all schools of every kind should be controlled by the State, and this principle is conceded by Parliament in the Act. It is not the business of the State to control all education because it is the State; but rather to encourage good work wherever it is being done, and to supplement the existing provision where the latter cannot cover the ground. Spiritual and intellectual liberties of the highest significance for the welfare of Britain are involved in this; and it is probable that if, as a condition of participating in this or any other scheme, the schools are asked to surrender their independence, they will have nothing further to do with the matter. They would, I believe, be unanimous in welcoming, as they are now under the Act required to accept, inspection by the Ministry, and personally I can see no objection to the inclusion of public representatives in the proportion suggested on the governing bodies. There, however, external supervision should stop.

There are a large number of details that will have to be worked out and which cannot, owing to limitations of space, be set out in this article-for example, the age of entry, methods of selection, the preparatory stage, assessment of parental and other contributions, agreement upon the standard fee, etc. Two general considerations can be urged at this stage. First, the schools are at present crowded to overflowing, the public demand for them is great; and it may therefore take some time for them to work up to the full 25 per cent, if that recommendation should be accepted. Secondly, the report makes a fine offer to boys who have been previously educated at primary schools, and we may hope that nobody will seek to encroach upon or limit that offer to those boys. But it remains true that very little is offered to parents in straitened circumstances, poor professional men, who have not sent their children to primary schools. In the interests of justice and equality it is clear that later on, if not now, measures will have to be taken to open the door to the children of these parents also.

During the last six years many pages have been written on the public schools, some of the authors being inspired by an irrational adulation of everything they do, and others by an equally irrational detestation of them and all their works. It may be hoped that during the months that are approaching all that sort of nonsense may be forgotten. The plain fact is that the schools have something to offer ; and the plain question is, How can that be made use of in the interests of the nation as a whole? The latest volume on the public schools is called "The Public Schools and the Nation"', by Dr. A. B. Badger*. This is based on some careful research going back to the sixteenth century. The general tone of the book is critical, and no one who values the contribution made in the past, and to be made in the future, by the public schools will ever object to having their faults candidly pointed out. The general effect of the book is somewhat confusing, as it consists so largely of quotations from the opinions of other people, many of them expressed a number of years ago, and applying, therefore, to conditions which have long since ceased to exist in the schools. Readers will welcome Dr. Badger's compilation and be grateful to him for his research; but the best of all guidance to future policy is to be found in personal, up-to-date, first-hand acqu nce with what the schools are and what they try

* The Public Schools and the Nation. By Dr. Alfred B. Badger. Pp. 160. (London: Robert Hale, Ltd., 1944.) 88. 6d. net.

\section{OBITUARIES}

\section{Sir Duncan Wilson, C.V.O., C.B.E.}

Str DUNCAN WILSON who, until his resignation in 1940 was chief inspector of factories, died suddenly on March 2 in his seventieth year. On leaving Eton he entered Magdalen College, Oxford, where he took his degree with first-class honours in natural science, and although his life-work has mainly been in administration, yet his scientific training proved a very valuable asset.

His official career falls roughly into three main periods. For fourteen years from 1904 he was a factory inspector; then came twelve years in which, as secretary, he organized the Industrial Fatigue (later Health) Research Board; after which he returned to his old department, first as deputy and then as chief.inspector of factories.

Perhaps the mid-period gave Sir Duncan the greatest opportunity to use his scientific knowledge and to express his individuality. The Industrial Fatigue Research Board was a very small organization, formed at the dissolution of the Health of Munition Workers' Committee at the end of the War of 1914-18, to apply the principles of physiology and psychology to research into industrial problems. In his first annual report published in 1920 he wrote, "The scientific study of the laws governing the healthy employment of the human mind and body in industry was strangely late in its development in this country, 